\title{
Adapting Problem-Based Learning to Meet the Life-long Learning Needs of Developmental Students
}

\author{
Brian Bielenberg and Maxine Gillway \\ United Arab Emirates University
}

\begin{abstract}
The United Arab Emirates University has implemented a unique adaptation of Problem-Based Learning (PBL) to meet the short, medium and long-term interdisciplinary developmental needs of its first-year university students (Learner Training, Thinking Skills, Application of Knowledge, Information Literacy, and Communication). This paper highlights the process of adapting PBL to the foundation year context and presents initial findings demonstrating its positive impact. These findings provide evidence that this adaptation of PBL supports the development of important life-long learning skills, can motivate and engage students, and enables them to make a variety of connections to other subjects, to other students (a community of learners), and to the broader community.
\end{abstract}

\section{Introduction}

Universities throughout the Gulf Region have set up special programs designed to meet the unique needs of the first-year student, ranging from independent seminars to full-scale preparatory years. Most often these programs focus on academic remediation in the areas of English language, mathematics, and ICT. A focus on academic skills in these areas is important; however, programs that limit their emphasis to basic skills and knowledge often do little to motivate the student or to provide them with the full range of tools needed to be successful in university and beyond. Student-centered opportunities to develop skills, knowledge and dispositions aimed at becoming life-long learners are more likely to motivate and engage. Problem-Based Learning (PBL) is one innovative methodology that shows great promise as a means for promoting acquisition of these skills, knowledge and dispositions. In most higher education institutions, the primary focus of PBL is normally on the discovery and application of content knowledge in a single discipline (Jonassen, 2000; Knowlton, 2003). In contrast, the use of PBL methodology in first-year programs provides a unique opportunity to focus more on the process of learning, as this is a central component of the PBL approach (Maricopa Community Colleges, 2006).

In this paper we highlight an adaptation of the PBL approach to the first-year experience that promotes the development and assessment of a set of interdisciplinary lifelong learning competencies: Learner Training, Thinking Skills, Application of Knowledge, Information Literacy, and Communication. The power of this approach as a means of meeting the short, medium, and long-term educational needs of Arab students is demonstrated through presentation of qualitative and quantitative data collected during the initial semester of implementation of PBL in the University General Requirements Unit (UGRU), the first-year developmental program of the United Arab Emirates University. These findings, obtained through focus groups, classroom observations, and formal course evaluations, provide evidence that the PBL experience in a first-year program can motivate and engage students to a greater

Bielenberg, B. and Gillway, M. (2007). Adapting problem-based learning to meet the life-long learning needs of developmental students. Learning and Teaching in Higher Education: Gulf Perspectives 4(1) (March 2007). http://www.zu.ac.ae/Ithe/lthe04_01_02_bielenberg.htm 
degree than traditional lecture-based courses. Participation in the PBL experience also enables students to make a variety of connections often missing from traditional courses: connections between subjects (mathematics-ICT-English-Study Skills), connections to the real world, connections between participants (a community of learners), and connections to the knowledge, skills and dispositions that will be needed for success in university and beyond.

\section{Reference Context}

The United Arab Emirates University (UAEU) is a four-year public institution with an enrollment of approximately 16,000 students. The University General Requirements Unit (UGRU) is the foundation level program within the university. UGRU consists of over 350 instructors and nearly 6,000 students. The average percentages of female and male students in the fall intake over the past 5 years have been $76 \%$ and $24 \%$, respectively. The vast majority, nearly $90 \%$, are first-generation university students (Bielenberg, 2005), defined as those whose parents have had no college or university experience. Nearly all UGRU students also enter with limited content area skills. The difficulties that may arise from this are compounded by the fact that student exposure to and abilities in academic English, the language they will need for most of their academic studies at UAEU, are limited.

As a first-year developmental program, UGRU aims to foster active, life-long learners able to tackle challenging, cross-disciplinary problems. Its mission is to equip students with the relevant knowledge and skills needed to function as a competent member of the university and society. As such, the UGRU curriculum focuses on both the process and the product of learning in order to develop students with not only a mastery of subject-specific core competencies, but also the ability to create, use and communicate knowledge. In fall 2003 a set of five UGRU Curriculum Competencies were adopted: learner training, thinking skills, application of knowledge, information literacy and communication. During spring 2004 specific teaching and learning objectives related to the UGRU Curriculum Competencies were woven into the Mathematics, English, ICT and Arabic course documents. While these objectives existed on paper, classroom observations and discussion with instructors indicated that their implementation in the classroom and opportunities to develop and assess them were limited. In response, UGRU sought to identify an engaging means for students to develop the Curriculum Competencies, and a tool to assess competency levels. PBL seemed to fit its needs.

\section{Problem-Based Learning}

The incorporation of Problem-Based Learning into formal education systems has been described as "a method [that] may change the nature of education" (Hung, et al, 2003). With PBL, students do much more than learn a body of knowledge to be regurgitated on an exam. As Ward and Lee (2002) point out, in PBL:

Students need to recognize what information is needed, have the knowledge and skill necessary to acquire this information, and the ability to use that knowledge appropriately to solve the problems they face (p. 17).

Problem-Based Learning was a term coined by Howard Barrows at McMaster University, Canada, in the 1960s. Involved in medical education, Barrows realized that doctors needed more than a body of knowledge - they needed the ability to draw on that knowledge as necessary and apply it to solving

Bielenberg, B. and Gillway, M. (2007). Adapting problem-based learning to meet the life-long learning needs of developmental students. Learning and Teaching in Higher Education: Gulf Perspectives 4(1) (March 2007). http://www.zu.ac.ae/Ithe/lthe04_01_02_bielenberg.htm 
problems with which they were faced in their clinical practices. What is more, they needed to be able to extend their knowledge throughout their careers. In today's information-rich society, this need is even more pressing for graduates of all fields. For students to be successful in the twenty first century they need to be lifelong learners. Helping them to develop the skills necessary to become lifelong learners, we argue, requires an approach like PBL.

Unlike a traditional project, which is usually designed to consolidate knowledge and demonstrate the relevance of what has already been taught, $\mathrm{PBL}$ is inductive in that it begins with the presentation of a real world scenario. This scenario provides the context and motivation for learning. The following process forms the basis of PBL methodology (based on Barrows, 1992):

- Small groups of students are presented with a real world 'messy' open-ended problem;

- The group analyzes the problem to establish what they know, what they need to know and how they can find out;

- The workload is distributed fairly and efficiently among the group;

- Individuals carry out their assigned task outside of the classroom;

- Individuals share their new knowledge with the group and apply it to the problem;

- The group re-conceptualizes the problem in the light of new knowledge and comes up with potential solutions;

- Solutions are communicated to a wider audience and justified in an authentic performance based assessment situation.

As the concept of PBL has spread beyond medical faculties, numerous studies have illustrated its potential to engage students and improve learning. PBL has been shown to help students take more responsibility for their learning (Lieux, 1996), improve cognitive skills (Chrispeels and Martin, 1998), become more motivated (MacKinnon, 1999), develop valuable social skills (Lieux, 1996), and learn more about themselves (Evensen et al., 2001). Important in PBL is that learners have ownership of the problem, that the learning is anchored to a larger task and that learners are challenged (MacKinnon, 1999).

The pure form of PBL outlined above has been successful in many contexts, but may not be appropriate for all students, particularly those who have come from a didactic, teacher-centered education system in which they have been expected to simply memorize, store and reproduce information with little opportunity to engage in critical thinking and problem solving. In such cases, students may require additional scaffolding to support their early efforts to work in a group, access and analyze information, and participate in the problem solving process. When components of more traditional teacher-centered approaches such as mini-lectures about knowledge, skills and dispositions in these areas and scaffolded guidelines are included in PBL, the process is termed hybrid PBL, a methodology that can potentially best serve the needs of the students typically entering the UAE University. 


\section{The UGRU PBL Experience Course}

The UGRU PBL initiative began in Spring 2004 when instructors from all subject areas were invited to contribute ideas on how to better engage students on the final day of the teaching week, Wednesdays, a day of high absenteeism and unengaged learning. Ideas included subject specific project weeks, service learning projects, guest speakers, and an extended tutorial system. The common theme was a project element. Discussions took place in various forums as to the shape of the new vision for Wednesday and after considerable research the recommendation was made to introduce a ProblemBased Learning component to the UGRU Curriculum. In Fall 2004, a team of volunteer teachers from all subject areas (English, Mathematics, ICT) was brought together and began work on developing scenarios, materials and assessment tools. The initial PBL experience was piloted in Spring 2005 with three sections of female students. Improvements were made in the wording of the problems and the facilitator (instructor) guidelines, and the experience was fully implemented in Fall 2005. This original initiative has come to be known as PBL2. An introductory level of the PBL experience was developed in spring 2005 and fully implemented in Spring 2006. Known in UGRU as PBL1, this form of the PBL experience has adaptations in terms of language requirements and is intended for students who are placed into the first level of UGRU English during their first semester of UGRU. By Spring 2006, both PBL1 and PBL2 were fully implemented, involving over 70 facilitators and nearly 3000 students.

In its present form, the PBL Experience course in UGRU takes place over the period of one 17 week semester each for both PBL1 and PBL2. In each level, small groups of students (4-5 per group) select and work throughout the course on a real world problem, applying knowledge and skills gained in other UGRU courses. During the problem solving process, a facilitator coaches groups on the metacognitive skills of setting goals, recording and monitoring action, reflecting on performance, and assessing progress. The final product includes two recommendations with relevant justification and support in the form of a poster or leaflet. The groups also present their recommendations to the class, usually in the form of a PowerPoint presentation. The key to the whole process is an authentic, engaging real-world problem.

\section{Scenarios}

Problem-Based Learning problems (known as scenarios in the UGRU PBL Experience Course) should be designed in such a way as to ensure that students must perform research to gather the information needed for possible solutions (Delisle, 1997). They should be developmentally appropriate, have a clear purpose, have available resources, and be curriculum based. The topics of scenarios for the UGRU PBL Experience are guided by the general themes worked on in the English program, which are Daily Life, Work and Business, Science and Nature, Sports and Leisure, and Nutrition and Health. Other characteristics of PBL problems are that they be current, relevant, complex, open-ended and ill-defined (Samford University, 2006). UGRU PBL problems are developed based on concerns raised by students, as well as those discussed in the popular press. By utilizing such sources, the cultural relevancy of the problems is ensured. These characteristics apply to the problem scenarios at both levels of the UGRU PBL Experience Course, although the nature of the scenarios presented to students differs. In PBL1, the students are given the choice of six student profiles and tasked with providing recommendations for two careers. They then present the two chosen careers to the facilitator with an analysis of the candidate's strengths and weaknesses for each career and advice on action to be taken to improve prospects. Through these scenarios students see the relevance of a career search and are able to apply some of the lessons learnt to their own lives. With these scenarios it was necessary to adapt the process to local

Bielenberg, B. and Gillway, M. (2007). Adapting problem-based learning to meet the life-long learning needs of developmental students. Learning and Teaching in Higher Education: Gulf Perspectives 4(1) (March 2007). http://www.zu.ac.ae/Ithe/lthe04_01_02_bielenberg.htm 
educational norms and cultural expectations. UAE University houses separate campuses for male and female students and, based on input from instructors, parents and administrators, we present only female profiles to female students and only male profiles to male students. UAE society is quite progressive in promoting female participation in the work force and government, and this "restriction" has actually resulted in female students being much more imaginative in terms of the career possibilities chosen.

In PBL2 the students are presented with a choice of three real world problems that are of current relevance to their life in the UAE. To date UGRU students have tackled parking problems, infant mortality, and water resources. A scenario bank is currently being developed and includes additional topics such as campus development, traffic accidents, stock market, graduate employment, tourism, library facilities, and sports and leisure facilities. Three different scenarios are presented to students each semester. Students themselves have indicated a desire to address societal issues such as the increase in divorce rate and the process of Emiratization of the work force, and problems around these topics are currently being developed. See Appendix 1 for a sample scenario.

\section{Task structure}

Both PBL1 and PBL2 students follow the same problem solving process as outlined in Table 1. Each session begins with students sharing information from their preparation task followed by discussions within the group. Next, individual responsibilities are allocated for the out-of-class preparation task, and each session ends with some form of self- or peer-assessment focusing primarily on the functioning of the group. Each session comes with a clear lesson plan and set of materials for facilitators to use in order to guide students through this process.

Table 1. The UGRU Problem-Based Learning Process

\begin{tabular}{|c|c|}
\hline Session & By the end of this session you will have... \\
\hline Orientation & $\begin{array}{l}\text { understood what PBL is and why we will do it; } \\
\text { thought about good group work. }\end{array}$ \\
\hline Session 1 & $\begin{array}{l}\text { formed groups and chosen a role; } \\
\text { understood the task and grading; } \\
\text { understood a chosen scenario. }\end{array}$ \\
\hline $\begin{array}{l}\text { Out of class } \\
\text { preparation }\end{array}$ & identified what you know and what you need to know. \\
\hline Session 2 & $\begin{array}{l}\text { shared knowledge and opinions on what you know and what you need to } \\
\text { know; } \\
\text { written research questions; } \\
\text { developed a search plan; } \\
\text { shared responsibilities. }\end{array}$ \\
\hline $\begin{array}{l}\text { Out of class } \\
\text { preparation }\end{array}$ & found information and taken notes. \\
\hline
\end{tabular}

Bielenberg, B. and Gillway, M. (2007). Adapting problem-based learning to meet the life-long learning needs of developmental students. Learning and Teaching in Higher Education: Gulf Perspectives 4(1) (March 2007). http://www.zu.ac.ae/Ithe/lthe04_01_02_bielenberg.htm 


\begin{tabular}{|l|l|}
\hline Session 3 & $\begin{array}{l}\text { presented information to your group; } \\
\text { brainstormed possible solutions to the problem; } \\
\text { selected relevant information; } \\
\text { identified gaps in information; } \\
\text { made a work plan. }\end{array}$ \\
\hline $\begin{array}{l}\text { Out of class } \\
\text { preparation }\end{array}$ & completed work plan. \\
\hline Session 4 & $\begin{array}{l}\text { shared results of individual work; } \\
\text { organized information for final product (poster/leaflet); } \\
\text { agreed meeting times/responsibilities. }\end{array}$ \\
\hline $\begin{array}{l}\text { Out of class } \\
\text { preparation }\end{array}$ & $\begin{array}{l}\text { produced draft poster/leaflet; } \\
\text { completed task sheet. }\end{array}$ \\
\hline Session 5 & $\begin{array}{l}\text { given feedback on other groups' posters/leaflets; } \\
\text { planned your presentation. }\end{array}$ \\
\hline $\begin{array}{l}\text { Out of class } \\
\text { preparation }\end{array}$ & $\begin{array}{l}\text { Finalized your poster/leaflet; } \\
\text { Practised and assessed own group's presentation. }\end{array}$ \\
\hline Session 6 & $\begin{array}{l}\text { taken part in final presentations; } \\
\text { written comments on the Wednesday PBL Experience Course. }\end{array}$ \\
\hline
\end{tabular}

\section{Assessment}

There is no traditional examination in the UGRU PBL Experience Course as the students are not expected to acquire subject specific knowledge. Rather, students develop knowledge, skills and attitudes in the UGRU Curriculum Competencies that are best assessed using alternative techniques. In addition to a self- or peer-assessment task in each session, there is a standardized teacher assessment component. This consists of the following three elements:

- Process: The problem solving process itself is central to the course and as such represents $30 \%$ of the final grade through continuous assessment. This consists of a series of individual tasks allocated by the group at the end of each session to be completed for the following session in order to allow the group to progress on schedule. The facilitator checks completion of tasks at the start of each session and awards a grade of 0 (not accomplished/does not meet minimal standards); 1 (Accomplished/meets minimal standards), or 2 (accomplished/exceeds minimal standards). The average of these 6 preparation tasks is entered as $30 \%$ of the final grade. This element of the grade will clearly differentiate between those members of a group who have been fully engaged in the process and those who have failed to perform as an effective group member.

- Product: This consists of a leaflet or poster that includes two recommendations on how to address the chosen problem, with relevant supporting details and justification, submitted to the 
facilitator in session 6. Facilitators use a standardized criteria sheet (see Appendix 2) to award a group grade to those students who have clearly contributed. Calibration sessions are carried out with facilitators prior to session 6 . The product counts for $30 \%$ of the final grade.

- Performance: In the final session the group is required to present their recommendations and explain their decision making process. Facilitators use a standardized criteria sheet (see Appendix 3 ) to assess group and individual performance in the presentation. This represents $40 \%$ of the final grade. Calibration sessions are carried out with facilitators prior to session 6.

\section{Professional Development}

The role of the instructor (facilitator in PBL) is substantially different from the traditional teacher role in a content area class. Rather than serving as a "sage on the stage," the PBL facilitator is expected to be "a guide by the side," facilitating the learning process without specifying the content to be learned (Stinson \& Milter, 1996). Instead of lectures, the facilitator is asked to model various methods of problem-solving and/or ask guiding, meta-cognitive questions such as "tell me about your group's thought process." This is sometimes referred to as "cognitive apprenticeship" learning (Collins et al., 1989). This change in instructor role can be frustrating for both students and teachers, especially in the initial stages of Problem-Based Learning (Zimitat \& Miflin, 2003). In response, on-going professional development has been an integral component of the UGRU PBL Experience. In our concept of professional development, the course developers work with teachers to identify issues and reflect on practice, an approach to professional development that puts instructors at the center of an examination of teaching practice. In June 2005 a 'PBL through PBL' experience was organized to allow future facilitators to experience the methodology that they would be using in order to discover the theory and practical implementation of PBL. This initial experience has been followed by sustained PD support whereby facilitators gather to preview the sessions before they are delivered and then meet again after each session to debrief and reflect on the lesson taught. There is also an electronic discussion board where facilitators are encouraged to share their experiences. Instructor input has led to many improvements in the UGRU PBL Experience materials and process.

\section{Program Assessment}

The design of the UGRU PBL Experience was in many ways successful because of the active involvement of instructors in the development process. This active involvement continued during the initial piloting and implementation of PBL in UGRU. As such, both instructors and administrators were anxious to determine the degree to which their PBL initiative was successful in motivating students and developing student knowledge, skills and dispositions in the areas of the five UGRU Curriculum Competencies. Four key areas were assessed: Student Motivation, Development of Curriculum Competencies, Instructor Development, and Connections.

In order to assess the items listed above a combination of qualitative and quantitative data gathered through teacher focus groups, classroom observations, and student and teacher course evaluations were used. The focus groups were held on a bi-weekly basis, with a total of thirty one teachers participating. Discussions during these sessions were guided by a set of questions distributed to facilitators prior to a given PBL session and completed immediately following the session. Student focus groups involved twenty students who met twice during the semester. Discussion notes were

Bielenberg, B. and Gillway, M. (2007). Adapting problem-based learning to meet the life-long learning needs of developmental students. Learning and Teaching in Higher Education: Gulf Perspectives 4(1) (March 2007). http://www.zu.ac.ae/Ithe/lthe04_01_02_bielenberg.htm 
compiled and key themes identified across sessions through careful analysis of the focus group discourse.

Course evaluation forms were completed by all thirty one teachers and 698 of 923 students during the last half hour of the final session of the PBL Experience (some sections with a large number of groups did not have time for students to complete the form). The course evaluation forms for both students and instructors parallel the forms that are used for course evaluation of all UGRU courses. These forms are subjected to annual review to ensure validity and reliability. The parallel forms allow for comparison across courses, including the PBL Experience. Both student and teacher forms were completed online, with responses to individual items given on a four-point Likert scale ranging from Strongly Agree to Strongly Disagree. Results were reported both as an average response and as a percentage of responses at a given level of agreement. The student course evaluation form consisted of 19 questions covering four main categories: General Issues, Course Documents, Assessment, and Curriculum Competencies. Sample questions for each area are presented in Table 2. The teacher course evaluation form paralleled the student form and also contained items in the areas of Facilitator Support, resulting in a total of 29 items.

Table 2. Sample Items for UGRU PBL Experience Course Evaluation

\begin{tabular}{|c|c|c|}
\hline Category & Student Item & Facilitator Item \\
\hline General & $\begin{array}{l}\text { The PBL Experience } \\
\text { course was useful. }\end{array}$ & $\begin{array}{l}\text { The PBL Experience } \\
\text { course is useful for } \\
\text { students. }\end{array}$ \\
\hline Course Documents & $\begin{array}{l}\text { I understood the } \\
\text { PBL FAQ. }\end{array}$ & $\begin{array}{l}\text { The information in } \\
\text { the FAQs is } \\
\text { understandable for } \\
\text { students. }\end{array}$ \\
\hline Assessment & $\begin{array}{l}\text { I believe my final } \\
\text { grade will accurately } \\
\text { reflect my overall } \\
\text { performance. }\end{array}$ & $\begin{array}{l}\text { The assessment } \\
\text { system accurately assesses } \\
\text { a student's level of } \\
\text { achievement. }\end{array}$ \\
\hline $\begin{array}{l}\text { Curriculum } \\
\text { Competencies }\end{array}$ & $\begin{array}{l}\text { PBL helped me learn } \\
\text { how to work well in a } \\
\text { small group. }\end{array}$ & $\begin{array}{l}\text { The PBL Experience } \\
\text { helps students learn how to } \\
\text { work effectively in a } \\
\text { group. }\end{array}$ \\
\hline
\end{tabular}

Both evaluation forms also included prompts for essay responses. The essay responses were read by a group consisting of two PBL facilitators, the UGRU curriculum development coordinator and the UGRU professional development coordinator. Initial readings coded the comments based on their relation to the five UGRU Curriculum Competencies (Learner Training, Thinking Skills, Communication, Information Literacy, and Application of Knowledge), as this is a major focus of the PBL Experience in UGRU. In addition, core concepts which appeared in over ten percent of comments were identified. These are: confidence, connections, responsibility, organizing skills, finding information, and usefulness. Comments referring to one or more of these concepts, whether positively or negatively, were coded for 
the term. Where discrepancies arose in the coding, the items were discussed and re-coded. Student and teacher responses were triangulated through classroom observations.

\section{Initial Findings and Discussion}

Overall, the PBL Experience has been found to motivate and engage students while also providing opportunities for them to develop in most areas of the Curriculum Competencies. Data also indicate that students developed a number of connections that will support their learning throughout their university education and beyond. Each of these assertions is discussed below, with supporting data provided.

When compared with other courses, students rate the PBL Experience as the most useful, as illustrated in Table 3. When students find a course useful, they are more likely to be engaged in the material. There are three aspects of the PBL Experience that could lead students to find it more "useful" than other courses. First, the focus of the PBL experience is on real world problems that are relevant to students' lives. Second, the methodology employed in the PBL Experience is substantially different from that encountered in other courses, with students having much more ownership over their learning. Third, the PBL Experience focuses on skills and dispositions toward learning that will benefit students throughout university and life. We argue that it is a combination of these three aspects that leads the largest percentage of students to rate the PBL Experience as useful. We base this assertion on comparison with, in particular, the UGRU ICT and Arabic (Study Skills) courses. The UGRU ICT curriculum is task-based, with students assigned real world tasks such as processing given information to determine possible means of reducing transportation costs of the university. The difference between the ICT course and the PBL Experience is the means by which students are presented information along with student ownership of the learning process. In the ICT classroom, it is the teacher who sets the agenda and determines what will be learned. In PBL, on the other hand, students are presented a choice of problems and take charge of the learning process, with the instructor serving as a "guide by the side."

Table 3. Comparison of Percent of Students Finding Courses Useful

\begin{tabular}{|l|c|}
\hline Course & $\begin{array}{c}\text { \% who find course } \\
\text { useful }\end{array}$ \\
\hline English & $56 \%$ \\
\hline Mathematics & $73 \%$ \\
\hline IT & $66 \%$ \\
\hline Arabic (Study Skills) & $72 \%$ \\
\hline PBL Experience & $92 \%$ \\
\hline
\end{tabular}

In the Arabic (Study Skills) course, students are introduced to different learning styles and decision making processes through a teacher-centered approach. While the content of this course is similar in focus to the learner training, information literacy and problem solving skills developed in PBL, the methods for promoting them differ substantially, with the Study Skills course "teaching" the skills as opposed to being learned through practice in the PBL Experience. Students indicate that they appreciate working together on important issues relevant to their lives, and feel in charge of their own 
learning. As one student put it, "[PBL] makes me feel like an important person in society." And although group work contributes to the enjoyment of many students, it is also mentioned by nearly $20 \%$ of students completing the PBL Experience evaluation as a de-motivating factor: "Group work is very useful and enjoyable, but when I work with lazy and irresponsible students it gets boring. The most difficult part is working with other students." In response, UGRU has provided more opportunities within the PBL Experience to reflect on group work and discuss ways to resolve conflict within groups. Finally, students report that participating in learning through PBL leads to increased confidence, which in turn results in more on task behavior.

Both students and teachers indicate that the PBL course strongly contributes to the development of the Curriculum Competencies. Information literacy (learning how to access information) and Learner Training (learning to work in a group, taking responsibility for one's work, and organizing one's work) were rated most highly by both facilitators and students. $85 \%$ of facilitators and $89 \%$ of students agree or strongly agree that the experience helps students learn how to find the information they need and how to use it. $96 \%$ of facilitators report that the experience helps students to improve their organization of information. And while students often found it difficult to analyze the vast amounts of information they accessed, a majority of those completing the essay responses identified this challenge as a major motivating factor. In other words, when presented with challenges that had an authentic purpose, students rose to the challenge and persisted in their efforts. In many ways this is summed up in the words of one of the PBL facilitators, who wrote, "Students' performance levels were all beyond my expectation and to be more accurate I should say way beyond my expectations." This comment was a dominant theme during facilitator focus groups and is one of the most positive benefits arising from implementation of the PBL Experience in our first year developmental program. As instructors have opportunities to see students being successful, and students experience success in a challenging endeavor, beliefs from both parties about what is possible have risen. Setting high standards and providing students with the scaffolding necessary to reach those high standards is becoming more and more common in UGRU classroom practice. UGRU instructors have also moved toward more studentcentered teaching in their regular courses with group work being more effectively used and $73 \%$ of teachers indicating that they now see the positive aspects of self- and peer-assessment tools. The developments in these areas are a direct consequence of participation as PBL facilitators.

The final area of positive impact from PBL is in terms of connections. Analysis of the comments on evaluation forms and classroom discourse indicates that PBL enables students to make connections with other learners, between subjects, to the community, to their future, and with their instructors. The connections to both short-term and long-term learning are evident in comments from students: "I am very happy about this PBL because I learned many things that will be useful in my life"; "It (PBL) was so good and this will help me in my faculty studies."

\section{Conclusion}

The evidence presented above provides initial insight into the positive impact that this curricular initiative has had for Arab students in a foundation year course. Hybrid PBL methodology is a motivating tool that enables the development, application and assessment of essential knowledge, skills and dispositions necessary for learning-for-life. PBL helps connect students both as a community of learners and to the broader community. Perhaps most importantly, the UGRU PBL Experience has contributed toward the transformation of the broader learning environment, providing a student-centered approach

Bielenberg, B. and Gillway, M. (2007). Adapting problem-based learning to meet the life-long learning needs of developmental students. Learning and Teaching in Higher Education: Gulf Perspectives 4(1) (March 2007). http://www.zu.ac.ae/Ithe/Ithe04_01_02_bielenberg.htm 
that engages students in active learning. In working towards this, we have learned many lessons. First is the need to involve students and instructors in the entire process, from the suggestion of scenarios to reflection on the learning process. Second, the learning must be anchored to a larger task that challenges students, with the necessary scaffolding provided to aid students in reaching high standards. As such, it is vital that appropriate and available resources be identified for all scenarios ahead of implementation. Students can easily become frustrated if too little or too much information is available to address a given problem. Third, academic language needs should be an ongoing aspect of discussions, particularly when a large number of students have English as a second or additional language, as is the case in the UAE. A final key to the success of PBL in the first-year experience is the incorporation of explicit opportunities for students and facilitators to reflect on group work.

The role of the instructor (Facilitator in PBL) is substantially different from the traditional teacher role in a content area class. This change in instructor role can be frustrating for both students and teachers, especially in the initial stages of Problem-Based Learning. On-going professional development is a critical element of any initiative of this sort. It is not enough to simply introduce the concept of PBL to instructors involved in facilitating PBL based first year-courses or seminars; instructors need to be provided with opportunities to work with course developers to identify issues and reflect on practice, an approach to professional development that puts instructors at the center of an examination of teaching practice. In our setting, this includes the widespread sharing of facilitator developed materials and guidelines.

In order to be successful in the twenty first century, universities must graduate students who are prepared to be life-long learners. This challenge necessitates a pedagogical shift from transmitting a body of expected knowledge that is largely memorized to one that is predominately process oriented. In this paper we have demonstrated that PBL is one methodology that can be effectively used in firstyear programs to accomplish this goal. It seems appropriate to end with the words of a student who participated in the first UGRU PBL Experience, "I enjoyed working with the group and feeling that our work is so important that we gave it most of our time and thoughts." When first year students approach learning with this attitude, the possibilities are endless.

\section{References}

Barrows, H.S. (1992). The Tutorial Process. Springfield, IL: Southern Illinois University School of Medicine.

Bielenberg, B.T. and Al-Khanbashi, A. (2005). Some General Characteristics of Entering UAEU Students: Meeting the Needs of the Next Generation. Proceedings of the 6th Annual UAEU Research Conference, Al Ain, UAE, April 21-24, 2005. Available at http://sra.uaeu.ac.ae/Conference_6/index.htm.

Collins, A., Brown, J.S. \& Newman, S.E. (1989). Cognitive apprenticeship: Teaching the craft of reading, writing and mathematics. In L.B. Resnick (Ed.), Knowing, learning and instruction: Essays in honor of Robert Glaser (pp. 453-494). Hillsdale, NJ: Erlbaum.

Chrispeels, J.H., \& Martin, K. J. (1998). Becoming Problem Solvers: The Case of Three Future Administrators. Journal of School Leadership, 8, pp. 303-331.

Bielenberg, B. and Gillway, M. (2007). Adapting problem-based learning to meet the life-long learning needs of developmental students. Learning and Teaching in Higher Education: Gulf Perspectives 4(1) (March 2007). http://www.zu.ac.ae/Ithe/lthe04_01_02_bielenberg.htm 
Delisle, R. (1997). How to Use Problem-Based Learning in the Classroom. Alexandria, VA: Association for Supervision and Curriculum Development.

Evensen, D.H., Slaisbury-Glennon, J. D., \& Glenn, J. (2001). A Qualitative Study of Six Medical Students in a Problem-Based Curriculum: Toward a Situated Model of Self-Regulation. Journal of Educational Psychology, 93(4), pp. 659-676.

Hung, W., Bailey, J.H., \& Jonassen, D.H. (2003). Exploring the Tensions of Problem Based Learning: Insights from Research. New Directions for Teaching and Learning, no. 95, pp. 13-23.

Jonassen, D. (2000). Toward a Design Theory of Problem Solving. Educational Technology Research and Development, 48(4), pp. 63-85.

Knowlton, D.S. (2003). Preparing students for educated living: Virtues of problem-based learning across the higher education curriculum. In D.S. Knowlton \& D.C. Sharp (Eds.), Problem-Based Learning in the Information Age. New Directions for Teaching and Learning, no. 95, 5-12.

Lieux, E.M. (1996). A Comparative Study of Learning in Lecture Vs. Problem-Based Format. About Teaching - \#50. A Newsletter of the Center for Teaching Effectiveness, Spring 1996, University of Delaware Available at http://www.udel.edu/pbl/cte/spr96-nutr.html. Accessed on 3 January 2007.

MacKinnon, M. M. (1999). CORE Elements of Student Motivation in Problem-Based learning. New Directions for Teaching and Learning, 78, pp. 49 - 58, Summer 1999.

Maricopa Community Colleges Center for Learning and Instruction (2006). Available at http://www.mcli.dist.maricopa.edu/pbl/info.html. Accessed on 3 January 2007.

Samford University Problem Based Learning Website (2006). Available at http://www.samford.edu/ctls/problem_based_learning.html. Accessed on 3 January 2007.

Stinson, J.E. and Milter, R.G. (1996). Problem-based learning in business education: curriculum design and implementation issues. Available at http://www.ouwb.ohiou.edu/this_is_ouwb/papers/paper3.htm. Accessed on 6 June 2006.

Ward, J. D., and Lee, C. L. (2002). A Review of Problem-Based learning. Journal of Family and Consumer Sciences Education, 20(1), Spring/Summer, 2002.

Zimitat, C. \& Miflin, B. (2003). Using Assessment to Induct Students and Staff into the PBL Tutorial Process. Assessment and Evaluation in Higher Education, 28(1), pp. $17-32$.

\section{Authors}

Dr. Brian Bielenberg, Professional Development Coordinator, United Arab Emirates University. Dr. Bielenberg has been involved in Developmental Education for five years. Prior to that he taught mathematics and ESL at the high school and university level.

Ms. Maxine Gillway, Curriculum Development Coordinator, United Arab Emirates University.

Bielenberg, B. and Gillway, M. (2007). Adapting problem-based learning to meet the life-long learning needs of developmental students. Learning and Teaching in Higher Education: Gulf Perspectives 4(1) (March 2007). http://www.zu.ac.ae/Ithe/lthe04_01_02_bielenberg.htm 


\section{Appendix 1: Sample problem scenario}

\section{ACCIDENTS IN THE UAE}

There are many traffic accidents in the UAE each year. The human and material losses are great. The UAE government wants to educate high school students on safe driving. They need ideas about the best way to do this.

You are a member of an advisory team working for the Ministry of the Interior. Your team must make two recommendations on how best to educate students on ways to drive safely. You must explain why your recommendations are good and will work (supporting evidence).

To solve the problem, you will need to collect information and make decisions based on the information you collect. You will need to produce a leaflet, poster, web page or digital video describing and explaining the problem, your recommendations and your supporting evidence.

In week 16/17, your team will present your solution to the UAE Minister of the Interior. 


\section{Appendix 2: Assessment criteria for the PBL product}

\begin{tabular}{|c|c|c|c|c|}
\hline The poster/leaflet... & Rating & & Comments & Who? \\
\hline \multicolumn{5}{|c|}{ CONTENT: things to include in the poster/leaflet (10) } \\
\hline Clearly states the problem. & 1 & 2 & & \\
\hline $\begin{array}{l}\text { Clearly makes TWO relevant } \\
\text { recommendations. }\end{array}$ & 1 & 2 & & \\
\hline $\begin{array}{l}\text { Clearly supports TWO } \\
\text { recommendations. }\end{array}$ & 0 & 2 & & \\
\hline $\begin{array}{l}\text { Clearly refers to sources of } \\
\text { information. }\end{array}$ & 1 & 2 & & \\
\hline $\begin{array}{l}\text { Contains relevant visuals } \\
\text { (tables/graphs/chart/pictures) }\end{array}$ & 1 & 2 & & \\
\hline \multicolumn{5}{|c|}{ FORMAT: how the poster/leaflet looks ( 6 ) } \\
\hline Is easy to read. & 1 & 2 & & \\
\hline $\begin{array}{l}\text { Has clear visuals. } \\
\text { (graphs/charts/pictures) }\end{array}$ & 0 & 2 & & \\
\hline Is well organized on the page(s). & 0 & 2 & & \\
\hline \multicolumn{5}{|c|}{ APPLICATION OF KNOWLEDGE: use of Math, ICT and English (6) } \\
\hline $\begin{array}{l}\text { Shows knowledge and skills in } \\
\text { English. }\end{array}$ & 0 & 2 & & \\
\hline Shows knowledge and skills in ICT. & 1 & 2 & & \\
\hline Shows knowledge and skills in Math. & 1 & 2 & & \\
\hline TOTAL SCORE & $/ 22$ & & & \\
\hline
\end{tabular}




\section{Appendix 3: Assessment criteria for the PBL group presentation}

\begin{tabular}{|c|c|c|c|c|}
\hline The presentation..... & Rating & & Comments & Who? \\
\hline \multicolumn{5}{|c|}{ CONTENT: things to include in the presentation } \\
\hline $\begin{array}{l}\text { Clearly states the problem } \\
\text { and why it was chosen. }\end{array}$ & 1 & 2 & & \\
\hline $\begin{array}{l}\text { Clearly describes what the } \\
\text { group members did. }\end{array}$ & 0 & 2 & & \\
\hline $\begin{array}{l}\text { Clearly makes two } \\
\text { recommendations. }\end{array}$ & 0 & 2 & & \\
\hline $\begin{array}{l}\text { Clearly supports two } \\
\text { recommendations. }\end{array}$ & 0 & 2 & & \\
\hline $\begin{array}{l}\text { Clearly refers to sources of } \\
\text { information. }\end{array}$ & 0 & 2 & & \\
\hline \multicolumn{5}{|c|}{ ORGANISATION: the way the presentation fits together } \\
\hline Includes a clear introduction. & 0 & 2 & & \\
\hline $\begin{array}{l}\text { Highlights key points verbally } \\
\text { or visually. }\end{array}$ & 0 & 2 & & \\
\hline $\begin{array}{l}\text { Uses logical connectors and } \\
\text { so is easy to follow. }\end{array}$ & 0 & 2 & & \\
\hline Includes a clear conclusion. & 0 & 2 & & \\
\hline
\end{tabular}

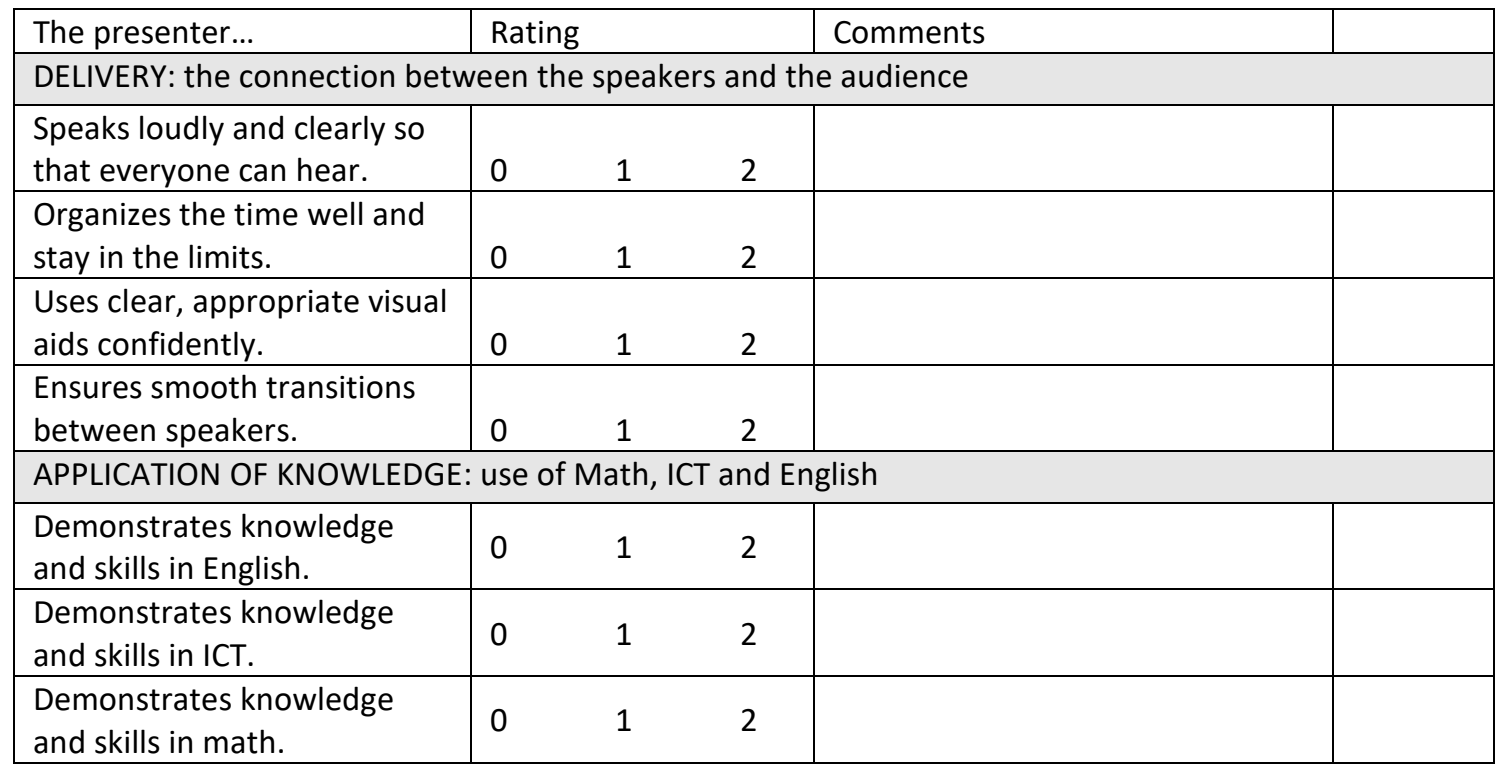

Rating Scale: $0=$ not demonstrated $1=$ needs improvement $2=$ satisfies requirements

Assessor $=\quad$ teacher $/$ student $($ please circle $)$ 